\title{
Presence of Antibodies against Bluetongue Virus (BTV) in Sheep 5 to 7.5 Years after Vaccination with Inactivated BTV-8 Vaccines
}

\author{
Johanna Hilke ${ }^{1,2, *}$, Heinz Strobel ${ }^{1}$, Soeren Woelke ${ }^{3}$, Melanie Stoeter ${ }^{2}$, Katja Voigt ${ }^{4}$, \\ Bernd Moeller ${ }^{5}$, Max Bastian ${ }^{3}$ and Martin Ganter ${ }^{2}$ \\ 1 Sheep Veterinary Practice Strobel, Am Hopfenberg 8, 89352 Stoffenried, Germany; \\ drheinzstrobel@t-online.de \\ 2 Clinic for Swine and Small Ruminants, Forensic Medicine and Ambulatory Service, University of Veterinary \\ Medicine Hannover, Foundation, Bischofsholer Damm 15, 30173 Hannover, Germany; \\ Melanie.Stoeter@tiho-hannover.de (M.S.); Martin.Ganter@tiho-hannover.de (M.G.) \\ 3 Friedrich-Loeffler-Institute, Federal Research Institute for Animal Health, Suedufer 10, \\ 17493 Greifswald-Riems, Germany; soeren.woelke@fli.de (S.W.); Max.Bastian@fli.de (M.B.) \\ 4 Clinic for Ruminants with Ambulatory and Herd Health Services, Ludwig-Maximilians-University Munich, \\ Sonnenstr. 16, 85764 Oberschleissheim, Germany; k.voigt@med.vetmed.uni-muenchen.de \\ 5 Friedrich-Loeffler-Institute, Institute of Farm Animal Genetics, Hoeltystr. 10, 31535 Neustadt, Germany; \\ Bernd.Moeller@fli.de \\ * Correspondence: johanna.hilke@tiho-hannover.de
}

Received: 26 March 2019; Accepted: 6 June 2019; Published: 8 June 2019

\begin{abstract}
Thirty-six female sheep, previously vaccinated against Bluetongue virus serotype 8 (BTV-8) using inactivated vaccines, were included in this field study. In Germany, vaccination was compulsory in 2008 and 2009, voluntary in 2010 and early 2011, and later, was prohibited in 2011. Due to their age, eighteen sheep had been vaccinated for two or more consecutive years, while a further eighteen animals had only been vaccinated once or not at all. The sheep were blood sampled five $(n=31)$ to 7.5 years $(n=5)$ after their last vaccination. All serum samples $(n=36)$ were tested for BTV group-specific antibodies by an ELISA (IDScreen ${ }^{\circledR}$ Bluetongue Competition assay, ID Vet). In five of the animals, the BTV-8 serotype-specific antibody titers were measured by serum neutralization (SN). The majority of sheep that were vaccinated annually for two or more years showed a positive ELISA (14/18 sheep) and a SN (two of two sheep) result 5 years after their last vaccination. Most of the sheep vaccinated fewer than twice showed a negative ELISA result 5 to 7.5 years after their last vaccination (13/18 animals). The three animals in this group tested by SN showed one negative and two positive results. This short communication is the first to describe the presence of BTV antibodies in sheep 5 to 7.5 years after vaccination with inactivated BTV-8 vaccines.
\end{abstract}

Keywords: bluetongue virus; sheep; vaccination; inactivated vaccine; antibody duration; BTV-8

\section{Introduction}

Bluetongue is a notifiable disease of ruminants caused by the Bluetongue virus (BTV), an RNA-virus (genus Orbivirus within the family Reoviridae) with currently 27 known serotypes [1-3]. The virus is primarily transmitted by Culicoides spp. midges $[4,5]$ and causes severe or even fatal disease. Sheep are the most susceptible species. Cattle were known to act as a virus reservoir without showing clinical symptoms until the BTV serotype 8 (BTV-8) epidemic in Northern Europe, when cattle were also clinically affected [6]. The disease can have a considerable economic impact due to the morbidity and mortality of livestock as well as movement restrictions and control measures [7]. 
When the BTV serotype 8 emerged for the first time in Northern Europe in 2006, Germany opted for a control strategy using inactivated vaccines [8]. During the vaccine licensing process, a vaccination trial was initiated in cattle and sheep, testing three different inactivated BTV-8 vaccines [9-11]. As these proved to be highly efficient and safe, the vaccines were initially provisionally licensed and later received a central marketing authorization by the European Medicines Agency (EMA). According to the manufacturers' instructions, all the vaccines confer immunity for the duration of one year. Following commercial availability of these vaccines, vaccination became mandatory for all domesticated ruminants in 2008 and 2009, followed by a voluntary vaccination programme from 2010 to 2011, and then vaccination was eventually prohibited. In 2012, Germany was declared BTV-free [8]. Despite the re-emergence of BTV-8 in France in 2015 [12], and in Switzerland in 2017 [13], within close proximity to the German border, Germany maintained a disease-free status until 12 December 2018 [14], when two cattle that did not show clinical symptoms were PCR-positive for BTV-8 in a routine monitoring sample. The BTV-4 has also circulated in France since 2017 [15], and, so far, no case has been detected in Germany despite ongoing surveillance. The BTV-8 strain, currently circulating, shows less viremia, pathogenicity, and vector competence than the previous BTV-8 strain [16]. Various studies have shown the presence of BTV neutralizing antibody $(\mathrm{nAb})$ in cattle for three to six years following an infection, as well as vaccination [17-20]. In sheep, nAbs are known to last for at least 2.5 years [18]. To the authors' knowledge, there are no reports in sheep of antibody persistence beyond that time frame, which led us to undertake this field investigation.

\section{Materials and Methods}

\subsection{Ethical Statement}

For this study the procedures on animals were approved by the ethics committee of the federal state government of Upper Bavaria, Germany, for farm 1-4 (Regierung von Oberbayern, Az. 55.2-1-54-2532.0-48-2016, 19 July 2016) and the ethics committee of the Lower Saxony State Office for Consumer Protection and Food Safety, Germany, for farm 5 (Niedersächsisches Landesamt für Verbraucherschutz und Lebensmittelsicherheit, Az. 33.8-42502-05-17A211, 13 Nov 2017) and were conducted in accordance with the German animal welfare legislation and the EU Directive 2010/63/EU for animal experiments.

\subsection{Sheep}

Thirty-six female sheep, all born before March 2011 and originating from five different farms, were included in the study (Table 1). All flocks had been vaccinated annually between 2008 and 2010/11 with different inactivated BTV-8 vaccines (Table 2).

Table 1. Details on animals, history of vaccination, and results of ELISA (BTV group-specific antibodies) and serum neutralization (SN, BTV-8 serotype-specific neutralising antibodies).

\begin{tabular}{|c|c|c|c|c|c|c|c|}
\hline ID & Date of Birth & Farm/Group ${ }^{1}$ & Breed & $\begin{array}{l}\text { Vaccinations } \\
2008-2011^{2}\end{array}$ & $\begin{array}{c}\text { ELISA } \\
{\left[\mathrm{P} / \mathrm{N} \%{ }^{3}\right]}\end{array}$ & $\begin{array}{c}\text { ELISA } \\
\text { [Status] }\end{array}$ & $\begin{array}{c}\mathrm{SN} \\
{\left[\mathrm{ND}_{50}{ }^{4}\right]}\end{array}$ \\
\hline 11,473 & 22.12 .2005 & $3 / \mathrm{A}$ & MLS $^{5}$ & 4 & 26.6 & Positive & \\
\hline 12,793 & 15.12 .2006 & $3 / \mathrm{A}$ & MLS & 4 & 139.8 & Negative & \\
\hline 12,713 & 15.01.2007 & $3 / \mathrm{A}$ & MLS & 4 & 108.3 & Negative & \\
\hline 12,313 & 18.01.2007 & $3 / \mathrm{A}$ & MLS & 4 & 122.8 & Negative & \\
\hline 13,163 & 16.12 .2007 & $3 / \mathrm{A}$ & MLS & $3-4$ & 5.6 & Positive & \\
\hline 13,373 & 16.12 .2007 & $3 / \mathrm{A}$ & MLS & $3-4$ & 6.5 & Positive & \\
\hline 13,443 & 16.12 .2007 & $3 / \mathrm{A}$ & MLS & $3-4$ & 8.3 & Positive & \\
\hline 5151 & 25.02 .2008 & $1 / \mathrm{A}$ & MLS & $3-4$ & 13.3 & Positive & 47.6 \\
\hline 1452 & 07.09.2008 & $2 / \mathrm{A}$ & MLS & $2-3$ & 7.4 & Positive & \\
\hline 22 & 01.10 .2008 & $2 / \mathrm{A}$ & MLS & $2-3$ & 5.9 & Positive & \\
\hline 32 & 06.10 .2008 & $2 / \mathrm{A}$ & MLS & $2-3$ & 5.9 & Positive & 47.6 \\
\hline 5541 & 13.10.2008 & $1 / \mathrm{A}$ & MLS & $2-3$ & 8.9 & Positive & \\
\hline
\end{tabular}


Table 1. Cont.

\begin{tabular}{|c|c|c|c|c|c|c|c|}
\hline ID & Date of Birth & Farm/Group ${ }^{1}$ & Breed & $\begin{array}{l}\text { Vaccinations } \\
2008-2011^{2}\end{array}$ & $\begin{array}{c}\text { ELISA } \\
{\left[\mathrm{P} / \mathrm{N} \%{ }^{3}\right]}\end{array}$ & $\begin{array}{l}\text { ELISA } \\
\text { [Status] }\end{array}$ & $\begin{array}{c}\mathrm{SN} \\
{\left[\mathrm{ND}_{50}{ }^{4}\right]}\end{array}$ \\
\hline 5711 & 20.10 .2008 & $1 / \mathrm{A}$ & MLS & $2-3$ & 8.7 & Positive & \\
\hline 1332 & 25.12.2008 & $2 / \mathrm{A}$ & MLS & $2-3$ & 8.2 & Positive & \\
\hline 14,283 & 01.01.2009 & $3 / \mathrm{A}$ & MLS & $2-3$ & 6.5 & Positive & \\
\hline 1264 & 11.02 .2009 & 4/A & $\mathrm{AS}^{6}$ & 2 & 8.5 & Positive & \\
\hline 5701 & 09.03.2009 & $1 / \mathrm{A}$ & MLS & 2 & 8.8 & Positive & \\
\hline 1392 & 22.05.2009 & 2/A & MLS & 2 & 73.7 & Negative & \\
\hline 5613 & 05.01.2010 & 3/A & MLS & $1-2$ & 114.5 & Negative & \\
\hline 13 & 07.01.2010 & $3 / \mathrm{A}$ & MLS & $1-2$ & 126.4 & Negative & 0.1 \\
\hline 1462 & 25.07 .2010 & $2 / \mathrm{A}$ & MLS & 1 & 112.5 & Negative & \\
\hline 1512 & 08.11.2010 & $2 / \mathrm{A}$ & MLS & $0-1$ & 105.4 & Negative & \\
\hline 971 & 20.12 .2010 & $1 / \mathrm{A}$ & MLS & 1 & 167.8 & Negative & \\
\hline 921 & 30.12 .2010 & $1 / \mathrm{A}$ & MLS & 1 & 170.5 & Negative & \\
\hline 1443 & 04.01.2011 & 3/A & MLS & $0-1$ & 150.7 & Negative & \\
\hline 1333 & 05.01.2011 & $3 / \mathrm{A}$ & MLS & $0-1$ & 125.5 & Negative & 56.6 \\
\hline 11,913 & 15.01.2011 & $3 / \mathrm{A}$ & MLS & $0-1$ & 157.4 & Negative & \\
\hline 1382 & 17.01 .2011 & $2 / \mathrm{A}$ & MLS & $0-1$ & 57.4 & Inconclusive & \\
\hline 931 & 19.01.2011 & $1 / \mathrm{A}$ & MLS & $0-1$ & 173.3 & Negative & \\
\hline 1463 & 19.01.2011 & $3 / \mathrm{A}$ & MLS & $0-1$ & 152.6 & Negative & \\
\hline 1852 & 25.02 .2011 & 2/A & MLS & $0-1$ & 86.3 & Negative & \\
\hline 894,565 & 07.01 .2010 & $5 / \mathrm{B}$ & $\mathrm{BHM}^{7}$ & 1 & 13.397 & Positive & \\
\hline 894,765 & 18.01 .2010 & $5 / \mathrm{B}$ & BHM & 1 & 53.18 & Inconclusive & \\
\hline 894,705 & 26.01 .2010 & $5 / \mathrm{B}$ & BHM & 1 & 10.956 & Positive & \\
\hline 894,635 & 27.01 .2010 & $5 / B$ & BHM & 1 & 110.287 & Negative & 12.6 \\
\hline 894,675 & 27.01.2010 & $5 / \mathrm{B}$ & BHM & 1 & 57.566 & Inconclusive & \\
\hline
\end{tabular}

${ }^{1}$ group $\mathrm{A}=5$ years and group $\mathrm{B}=7.5$ years since last vaccination, ${ }^{2}$ the number of vaccinations was estimated taking into account the flock vaccination records and the date of birth of the animal, ${ }^{3}$ percentage negativity, ${ }^{4}$ neutralizing dose $50,{ }^{5}$ merino land sheep, ${ }^{6}$ alpine sheep, ${ }^{7}$ black headed mutton.

Table 2. Vaccines used in vaccinations 2008-2011. Bluevac ${ }^{\circledR}$ BTV8 (CZ Veterinaria S.A., Porrino, Spain); Bovilis ${ }^{\circledR}$ BTV8 (Intervet International BV, Boxmeer, the Netherlands), BTVPUR ${ }^{\circledR}$ AlSap 8 (Merial S.A.S., Lyon, France); Zulvac ${ }^{\circledR} 8$ Ovis (Fort Dodge Animal Health, Naarden, the Netherlands); n/k = vaccine not known.

\begin{tabular}{ccccc}
\hline Farm & 2008 & 2009 & 2010 & 2011 \\
\hline 1 & June, Bluevac ${ }^{\circledR}$ BTV8 & April, Bovilis ${ }^{\circledR}$ BTV8 & April, BTVPUR ${ }^{\circledR}$ AlSap 8 & August, Zulvac ${ }^{\circledR} 8$ Ovis \\
2 & July, Bluevac ${ }^{\circledR}$ BTV8 & June, Bovilis ${ }^{\circledR}$ BTV8 & May, n/k & April, n/k \\
3 & May, Bluevac ${ }^{\circledR}$ BTV8 & April, Bovilis ${ }^{\circledR}$ BTV8 & April, Bovilis ${ }^{\circledR}$ BTV8 & April, Zulvac ${ }^{\circledR}$ 8 Ovis \\
4 & January, & January, BTVPUR ${ }^{\circledR}$ AlSap 8 & January, BTVPUR ${ }^{\circledR}$ AlSap 8 & January, BTVPUR ${ }^{\circledR}$ AlSap 8 \\
5 & $\mathrm{n} / \mathrm{k} / \mathrm{k}$ & $\mathrm{n} / \mathrm{k}$ & June, BTVPUR ${ }^{\circledR}$ AlSap 8 & No vaccinations \\
\hline
\end{tabular}

In Germany, vaccinations in sheep are usually documented based on the flock level, not individually. Therefore, annual flock vaccination records did not allow us to establish the exact age of initial vaccination for the ewe lambs that were included in the annual vaccination programmes. Therefore, we assumed ewe lambs would have been vaccinated for the first time between three and nine months of age. This leads to a degree of uncertainty as to how many vaccinations the individual sheep received during the time period of this field study (Table 1).

\subsection{Group A: Five Years after Last Vaccination}

Thirty-one sheep from four different farms, all located in the federal state of Bavaria, Southern Germany, were sampled during the summer of 2016, i.e., 5 years after their last BTV vaccination in 2011. In the rural district of farms 2 and 3, one BTV-8 PCR positive ruminant was detected in August 2008, which was the only BTV finding in this rural district ever [21]. The animals from farm 2 included in this study were all born after this case (Table 1). This flock was checked daily for clinical symptoms, however no signs of disease were ever detected. The animals of farm 3 were vaccinated three months before the mentioned case, and therefore we considered them protected if any BTV- 8 had 
been circulating. No positive animals were found in the surrounding districts of farms 1 and 4 . Thus, all flocks were not considered to be naturally infected by BTV-8.

According to the farm records, eighteen sheep in this group were vaccinated annually for at least two years, whereas thirteen sheep were only vaccinated fewer than twice.

\subsection{Group B: 7.5 Years after Last Vaccination}

Five sheep on farm 5, located in the federal state of Lower Saxony, Northern Germany, were sampled in the winter of 2017, i.e., 7.5 years after their last BTV vaccination in 2010. The region had been affected by BTV-8 in 2008, with the last positively tested animal in the respective district confirmed on 8 December 2008 [21]. As the animals in our study were born in 2010, exposure to a natural BTV-8 infection was excluded. All five animals had been vaccinated once.

Blood samples were collected from the jugular vein or the vena cava [22]. The centrifuged $(2300 \times g$ for $5 \mathrm{~min}$ ) and decanted serum samples were stored at $-20{ }^{\circ} \mathrm{C}$ until testing.

\subsection{ELISA}

All serum samples $(n=36)$ were tested for BTV group-specific antibody activities using a commercial competitive ELISA (ID Screen ${ }^{\circledR}$ Bluetongue Competition assay, IDvet, Grabels, France) in accordance with the manufacturer's instructions at the Clinic for Swine and Small Ruminants, University of Veterinary Medicine Hannover, Germany. The results were expressed as percentage negativity $(\mathrm{PN})$ as compared with the negative control. The results were classified as positive $(\mathrm{PN} \leq 50)$, inconclusive $(50<\mathrm{PN}<60)$, or negative $(\mathrm{PN} \geq 60)$ in accordance with the cut-offs provided by the manufacturer. This competitive ELISA was validated [23] and showed a measurement sensitivity of 100\% (CI95\%: $99.49-100 \%, n=754$ cattle, sheep, goats) and a measurement specificity of $100 \%$ (CI95\%: 99.84-100\%, $\mathrm{n}=2461$ cattle, sheep, goats) (personal communication K. Klewer-Fromentin, IDvet, Grabels, France).

\subsection{Serum Neutralization Test (SNT)}

Serotype-specific neutralizing antibody $(\mathrm{nAb})$ titers against BTV-8 were measured in five serum samples. These tests were carried out at the Friedrich-Loeffler-Institute (FLI), Federal Research Institute for Animal Health, Isle of Riems, Germany.

Heat inactivated serum samples were diluted five-fold in cell medium, RPMI 1640 (Biochrom, Berlin, Germany) containing $2 \%$ foetal calf serum, l-glutamin ( $2 \mathrm{mM}$, biochrom) and penicillin/streptomycin (100 IU/mL, Biochrom). Subsequently, sera were serially diluted two-fold. For each dilution, $50 \mu \mathrm{L}$ were mixed in quadruplicate with $50 \mu \mathrm{L}$ cell medium containing $1 \times 10^{2} \mathrm{CCID} 50$ BTV-8. This virus was isolated by the National Bluetongue Reference Laboratory at the FLI from a German dairy cow in 2007 and since then has been maintained as a reference isolate using a seed lot system. The sera were co-incubated with virus for $3 \mathrm{~h}$ at $37^{\circ} \mathrm{C}$ and afterwards added to near confluent layers of Madin-Darby bovine kidney (MDBK) cells in 96-well flat bottom microtiter plates. After incubation for 2-3 days at $37^{\circ} \mathrm{C}$, the monolayer was scored for cytopathic effect. Neutralizing titers were given as neutralizing dose $50\left(\mathrm{ND}_{50}\right)$ per milliliter, which was calculated from the reciprocal of the highest serum dilution that caused virus neutralization in $50 \%$ of the tested quadruplicates using the method developed by Spearmann and Kaerber [24].

\section{Results}

\subsection{Group A: Five Years after Last Vaccination}

In total, 16 out of the 31 animals were ELISA and/or SNT positive five years after the last vaccination with an inactivated BTV-8 vaccine (Table 1). 
Of those sheep vaccinated at least twice between 2008-2011, 14/18 were ELISA positive. Two animals in this group (ID 5151 and ID 32) were analyzed for serotype-specific nAb and were highly positive for BTV-8 (both animals with a $\mathrm{ND}_{50}$ of 47.6 ).

Of those sheep vaccinated less than twice between 2010-2011, 12/13 showed negative ELISA results. In the remaining animal (ID 1382) the ELISA result was inconclusive. Two animals in this group were tested using the SNT. One of them showed no serotype-specific nAb activity at all (ID 13). The other animal (ID 1333) was highly positive for BTV-8 ( $\mathrm{ND}_{50} 56.6$ ), while showing no pan-BTV antibody activity by ELISA.

\subsection{Group B: 7.5 Years after Last Vaccination}

Two of the five animals tested positive by ELISA 7.5 years after the last vaccination (Table 1). Another two of the five animals showed inconclusive ELISA results. The remaining ELISA-negative animal (ID 894635) was positive to BTV-8 nAb by SNT (ND50 12.6).

\section{Discussion}

According to our analyses, the majority of sheep vaccinated annually for two or more consecutive years were BTV seropositive five years after their last vaccination with an inactivated BTV-8 vaccine (14 of 18 sheep). The majority of animals which had received only one vaccination showed ELISA or SNT negative results (15 of 18 sheep) five to 7.5 years after the last flock vaccination. However, 7.5 years after only one vaccination, two of five animals showed a positive ELISA and another animal (1 of 5 ) tested positive for the BTV-8 nAbs.

Although our study included only a small number of animals, we were able to prove a longer duration of the $\mathrm{nAb}$ than expected and presumed by the vaccine manufacturers. This supports other studies in cattle, which proved a BTV nAb duration after inactivated vaccines for three years [17], four years [18] and even six years [19]. To our knowledge, BTV nAb has only been shown to persist in sheep for a maximum of 2.5 years following vaccination with an inactivated vaccine [18].

Inactivated BTV vaccines are considered to protect from disease and viremia by stimulating both the humoral and cellular arms of the immune system [11,25-27]. Cytotoxic T-cells are assumed to be involved in cross-serotype protection [11,27-29]. The BTV-group-specific Abs against the inner capsid protein VP7 are detected by ELISA, whereas their role in protective immunity is unclear [30]. The serotype-specific nAbs are directed against outer capsid proteins VP2, and to a smaller extent against VP5 [25]. These immunogenic components do not necessarily correspond to each other, which was also seen in two animals in our study (ID 1333 and ID 894635) that showed a negative ELISA and a positive SNT result. The detection of viremia after virus challenge is, therefore, considered the most straight-forward and meaningful way to assess vaccine efficacy [31]. However, it was beyond the scope of this field study to perform a challenge experiment. Previous studies on persisting nAbs [17-19] all lack a virus challenge, but rely on studies showing that nAbs are highly correlated with protection from disease [26,31-33]. The small amount of SN tests was a limitation of our study. Nevertheless, in previous challenge studies, individual animals were protected while showing ELISA positive and SNT negative results [9], ELISA negative results [11] or even negative results in both tests [29,34]. Therefore, it was assumed that at least the animals that showed either ELISA or SNT positive results would be protected in the case of infection. However, further research is needed to confirm this assumption by these challenge studies.

The BTV was eliminated by a compulsory vaccination campaign in 2008 and 2009, followed by voluntary vaccinations in 2010 and 2011 [8]. It is postulated that the success of this relatively short campaign might have been supported by the long duration of protective antibodies after infection and especially after vaccination with inactivated BTV vaccines [17].

Due to the close genetic relationships between strains in 2008 and 2015, it is assumed that BTV-8 circulated at a low level in France between 2008 and 2015 [35]. Bournez et al. [36] supposed that 
animals were tested PCR positive when the herd immunity sank below an estimated level of $20 \%$ in cattle [36].

As it is unpredictable to what extent a circulating BTV-8 strain might become more virulent, pathogenic and/or vector competent when encountering an immunologically naive ruminant population, vaccinations are still highly recommended. According to our results, re-evaluating the current vaccination schemes might be an option, as already proposed by Ayrle et al. [19].

Economic considerations often prevent flock vaccinations against BTV. In view of the long duration of immunity observed in this current study, it should be tested whether an initial immunization consisting of two doses in the first year, followed by a single injection in the second year, would protect the flock from viremia and clinical signs for several years. By considering the age distribution within the flocks it may be possible to maintain sufficient flock protection by immunizing replacements only (two doses in the first year, followed by an additional vaccination in the second year). Revaccination of the whole flock would depend on the replacement rate. At an average replacement rate of $15.5 \%$ $(10-22 \%)$ in Southern Germany [37], a vaccination coverage of between $60 \%$ and $100 \%$ would be achieved in the sixth year. In flocks with lower than a $15 \%$ replacement rate, whole-flock revaccination might be necessary after five years to ensure sufficient cover to stop virus spread, as well as viremia, and to avoid the occurrence of clinical symptoms. This could be an animal friendly and economic control strategy for flocks situated in a BTV restricted area with no need to be moved. For those flocks and individual animals which leave the BTV restricted zone, annual vaccination after the initial boosted vaccination should remain mandatory to ensure virus control.

Author Contributions: Conceptualization, M.G., J.H., and H.S.; methodology, M.G., H.S., M.B., and J.H.; validation, J.H., M.G., and M.B.; investigation, J.H., K.V., M.S., S.W., and B.M.; resources, K.V., M.G., M.B., H.S., and B.M.; writing—original draft preparation, J.H.; writing—review and editing, J.H., H.S., K.V., M.B., M.G., M.S., S.W., and B.M.; supervision, M.G., M.B., and H.S.

Funding: This publication was supported by Deutsche Forschungsgemeinschaft and University of Veterinary Medicine Hannover, Foundation within the funding programme Open Access Publishing.

Acknowledgments: The authors are grateful to all sheep farmers involved in this study. We would like to thank Anna Morgenroth for her excellent technical assistance in SNT procedures, Bernd Hoffmann and Sven Reiche (all from the Friedrich-Loeffler-Institute, Isle of Riems, Germany) for providing the BTV-8 virus strain and MDBK-cells for the SNTs. We would also like to acknowledge the help of Lucie Grimm, Theresa Punsmann, Johanna Meilwes, and Matthias Wagener (all from the Clinic for Swine and Small Ruminants, Forensic Medicine and Ambulatory Service, University of Veterinary Medicine Hannover, Germany) in blood sampling on farm 5. We would like to thank Frances Sherwood-Brock for linguistically proofreading the manuscript.

Conflicts of Interest: The authors declare no conflict of interest.

\section{References}

1. OIE-Listed Diseases 2018: OIE-World Organisation for Animal Health. Available online: http://www.oie. int/en/animal-health-in-the-world/oie-listed-diseases-2018/ (accessed on 18 October 2018).

2. Verwoerd, D.W.; Louw, H.; Oellermann, R.A. Characterization of Bluetongue Virus Ribonucleic Acid. J. Virol. 1970, 5, 1-7. [PubMed]

3. Belbis, G.; Zientara, S.; Bréard, E.; Sailleau, C.; Caignard, G.; Vitour, D.; Attoui, H. Bluetongue Virus: From BTV-1 to BTV-27. In Advances in Virus Research; Elsevier: Amsterdam, The Netherlands, 2017; Volume 99, ISBN 978-0-12-812598-4.

4. Du Toit, R.M. The Transmission of Blue-Tongue and Horse-Sickness by Culicoides. Onderstepoort J. Vet. Sci. Anim. Ind. 1944, 19, 7-16.

5. Wilson, A.J.; Mellor, P.S. Bluetongue in Europe: Past, present and future. Philos. Trans. R. Soc. B Biol. Sci. 2009, 364, 2669-2681. [CrossRef]

6. Conraths, F.J.; Gethmann, J.M.; Staubach, C.; Mettenleiter, T.C.; Beer, M.; Hoffmann, B. Epidemiology of Bluetongue Virus Serotype 8, Germany. Emerg. Infect. Dis. 2009, 15, 433-435. [CrossRef] [PubMed]

7. Gethmann, J.; Probst, C.; Sauter-Louis, C.; Conraths, F.J. Economic analysis of animal disease outbreaks-BSE and Bluetongue disease as examples. Berliner und Munchener Tierarztliche Wochenschrift 2015, 128, 478-482. 
8. Baetza, H.-J. Eradication of bluetongue disease in Germany by vaccination. Vet. Immunol. Immunopathol. 2014, 158, 116-119. [CrossRef] [PubMed]

9. Eschbaumer, M.; Hoffmann, B.; König, P.; Teifke, J.P.; Gethmann, J.M.; Conraths, F.J.; Probst, C.; Mettenleiter, T.C.; Beer, M. Efficacy of three inactivated vaccines against bluetongue virus serotype 8 in sheep. Vaccine 2009, 27, 4169-4175. [CrossRef]

10. Gethmann, J.; Hüttner, K.; Heyne, H.; Probst, C.; Ziller, M.; Beer, M.; Hoffmann, B.; Mettenleiter, T.C.; Conraths, F.J. Comparative safety study of three inactivated BTV-8 vaccines in sheep and cattle under field conditions. Vaccine 2009, 27, 4118-4126. [CrossRef]

11. Wäckerlin, R.; Eschbaumer, M.; König, P.; Hoffmann, B.; Beer, M. Evaluation of humoral response and protective efficacy of three inactivated vaccines against bluetongue virus serotype 8 one year after vaccination of sheep and cattle. Vaccine 2010, 28, 4348-4355. [CrossRef]

12. Sailleau, C.; Bréard, E.; Viarouge, C.; Vitour, D.; Romey, A.; Garnier, A.; Fablet, A.; Lowenski, S.; Gorna, K.; Caignard, G.; et al. Re-Emergence of Bluetongue Virus Serotype 8 in France, 2015. Transbound. Emerg. Dis. 2017, 64, 998-1000. [CrossRef]

13. OIE World Animal Health Information System BTV Switzerland. Available online: http://www.oie.int/wahis_ 2/public/wahid.php/Reviewreport/Review?page_refer=MapFullEventReport\&reportid=25166 (accessed on 16 March 2019).

14. Radar_Bulletin_Deutschland-Dezember_2018_oeffentlich.pdf. Available online: https://www.openagrar. de/servlets/MCRFileNodeServlet/openagrar_derivate_00019395/Radar_Bulletin_Deutschland-Dezember_ 2018_oeffentlich.pdf (accessed on 3 January 2019).

15. OIE World Animal Health Information System BTV4 France. Available online: http://www.oie.int/wahis_2/ public/wahid.php/Reviewreport/Review?page_refer=MapFullEventReport\&reportid=21777 (accessed on 16 March 2019).

16. Flannery, J.; Sanz-Bernardo, B.; Ashby, M.; Brown, H.; Carpenter, S.; Cooke, L.; Corla, A.; Frost, L.; Gubbins, S.; Hicks, H.; et al. Evidence of reduced viremia, pathogenicity and vector competence in a re-emerging European strain of bluetongue virus serotype 8 in sheep. Transbound. Emerg. Dis. 2019, 66, 1177-1185. [CrossRef] [PubMed]

17. Oura, C.A.L.; Edwards, L.; Batten, C.A. Evaluation of the humoral immune response in adult dairy cattle three years after vaccination with a bluetongue serotype 8 inactivated vaccine. Vaccine 2012, 30, 112-115. [CrossRef] [PubMed]

18. Batten, C.A.; Edwards, L.; Oura, C.A.L. Evaluation of the humoral immune responses in adult cattle and sheep, 4 and 2.5 years post-vaccination with a bluetongue serotype 8 inactivated vaccine. Vaccine 2013, 31, 3783-3785. [CrossRef] [PubMed]

19. Ayrle, H.; Mevissen, M.; Kaske, M.; Vögtlin, A.; Fricker, R.; Hoffmann, B.; Büttner, M.; Marinovic, Z.; Walkenhorst, M. Colostral transmission of BTV-8 antibodies from dairy cows six years after vaccination. Vaccine 2018, 36, 5807-5810. [CrossRef] [PubMed]

20. Eschbaumer, M.; Eschweiler, J.; Hoffmann, B. Long-term persistence of neutralising antibodies against bluetongue virus serotype 8 in naturally infected cattle. Vaccine 2012, 30, 7142-7143. [CrossRef] [PubMed]

21. TSIS-TierSeuchenInformationsSystem Günzburg/Hannover. Available online: https://www.tsis.fli.de/ Reports/Info_SO.aspx?ts=009\&guid=e61d7ae9-20ee-457c-b78b-d852c4f476d2 (accessed on 16 March 2019).

22. Ganter, M. Blood sampling from the vena cava cranialis in sheep and goat using sampling systems armed by canula. Tierärztliche Praxis Ausgabe G: Großtiere/Nutztiere 2001, 29, 37-40.

23. Vandenbussche, F.; Vanbinst, T.; Verheyden, B.; van Dessel, W.; Demeestere, L.; Houdart, P.; Bertels, G.; Praet, N.; Berkvens, D.; Mintiens, K.; et al. Evaluation of antibody-ELISA and real-time RT-PCR for the diagnosis and profiling of bluetongue virus serotype 8 during the epidemic in Belgium in 2006. Vet. Microbiol. 2008, 129, 15-27. [CrossRef] [PubMed]

24. Mayr, A.; Bachmann, P.; Bibrack, B.; Wittmann, G. Quantitative Bestimmung der Virusinfektiösität (Virustitration). In Virologische Arbeitsmethoden; Gustav Fischer Verlag: Jena, Germany, 1974; Volume 1, pp. 35-39.

25. Schwartz-Cornil, I.; Mertens, P.P.C.; Contreras, V.; Hemati, B.; Pascale, F.; Bréard, E.; Mellor, P.S.; MacLachlan, N.J.; Zientara, S. Bluetongue virus: Virology, pathogenesis and immunity. Vet. Res. 2008, $39,46$. [CrossRef] 
26. Lobato, Z.I.P.; Coupar, B.E.H.; Gray, C.P.; Lunt, R.; Andrew, M.E. Antibody responses and protective immunity to recombinant vaccinia virus-expressed bluetongue virus antigens. Vet. Immunol. Immunopathol. 1997, 59, 293-309. [CrossRef]

27. Umeshappa, C.S.; Singh, K.P.; Pandey, A.B.; Singh, R.P.; Nanjundappa, R.H. Cell-mediated immune response and cross-protective efficacy of binary ethylenimine-inactivated bluetongue virus serotype-1 vaccine in sheep. Vaccine 2010, 28, 2522-2531. [CrossRef]

28. Jeggo, M.H.; Wardley, R.C.; Brownlie, J. Importance of ovine cytotoxic T cells in protection against bluetongue virus infection. Prog. Clin. Biol. Res. 1985, 178, 477-487. [PubMed]

29. Breard, E.; Belbis, G.; Viarouge, C.; Nomikou, K.; Haegeman, A.; De Clercq, K.; Hudelet, P.; Hamers, C.; Moreau, F.; Lilin, T.; et al. Evaluation of adaptive immune responses and heterologous protection induced by inactivated bluetongue virus vaccines. Vaccine 2015, 33, 512-518. [CrossRef] [PubMed]

30. Darpel, K.E.; Monaghan, P.; Anthony, S.J.; Takamatsu, H.-H.; Mertens, P.P.C. Bluetongue virus in the mammalian host and the induced immune response. In Bluetongue; Elsevier: Amsterdam, The Netherlands, 2009; pp. 265-284. ISBN 978-0-12-369368-6.

31. Savini, G.; MacLachlan, N.J.; Sánchez-Vizcaino, J.-M.; Zientara, S. Vaccines against bluetongue in Europe. Comp. Immunol. Microbiol. Infect. Dis. 2008, 31, 101-120. [CrossRef] [PubMed]

32. Oura, C.A.L.; Wood, J.L.N.; Sanders, A.J.; Bin-Tarif, A.; Henstock, M.; Edwards, L.; Floyd, T.; Simmons, H.; Batten, C.A. Seroconversion, neutralising antibodies and protection in bluetongue serotype 8 vaccinated sheep. Vaccine 2009, 27, 7326-7330. [CrossRef] [PubMed]

33. Jeggo, M.H.; Wardley, R.C.; Taylor, W.P. Role of neutralising antibody in passive immunity to bluetongue infection. Res. Vet. Sci. 1984, 36, 81-86. [CrossRef]

34. Stott, J.; Barber, T. Osburn BI Immunologic response of sheep to inactivated and virulent bluetongue virus. Am. J. Vet. Res. 1985, 46, 1043-1049.

35. Bréard, E.; Sailleau, C.; Quenault, H.; Lucas, P.; Viarouge, C.; Touzain, F.; Fablet, A.; Vitour, D.; Attoui, H.; Zientara, S.; et al. Complete Genome Sequence of Bluetongue Virus Serotype 8, Which Reemerged in France in August 2015. Genome Announc. 2016, 4, e00163-16. [CrossRef]

36. Bournez, L.; Cavalerie, L.; Sailleau, C.; Bréard, E.; Zanella, G.; Servan de Almeida, R.; Pedarrieu, A.; Garin, E.; Tourette, I.; Dion, F.; et al. Estimation of French cattle herd immunity against bluetongue serotype 8 at the time of its re-emergence in 2015. BMC Vet. Res. 2018, 14, 65. [CrossRef]

37. Frohnmayer, S.C. Betriebsanalyse zu Produktionskennzahlen und Lämmerverlusten in baden-württembergischen Schäfereien; Ludwig-Maximilians-University: Munich, Germany, 2015. 